\title{
Sistem Aplikasi Penentu Gaji Karyawan pada UD. Mebel DM Menggunakan Metode AHP Berbasis Website
}

\author{
Isbalaikana Larasati $^{1}$, Fitri Marisa ${ }^{2}$ \\ ${ }^{1}$ Isbalaikana.laras@ gmail.com, ${ }^{2}$ fitrimarisa@widyagama.ac.id \\ Program Studi Teknik Informatika, Universitas Widyagama Malang
}

\begin{abstract}
AHP (Analitycal Hierarchy Process) is a method to help take a certain decision according to the criteria. In this case have criteria that is discipline, responsibility, commitment, honest, and ethics. To help calculate the AHP method is determined a weight on each criteria to make it easier in the next calculation. The final result obtained is the process of addition of each criteria by having the highest yield 1.559545999
\end{abstract}

Intisari- AHP (Analitycal Hierarchy Process) merupakan metode untuk membantu mengambil suatu keputusan tertentu yang sesuai dengan kriteria. Dalam permasalahan ini mempunyai kriteria yaitu kedisiplinan, tanggung jawab, komitmen, jujur, dan etika. Untuk mebantu perhitungan metode AHP ini ditentukan sebuah bobot pada setiap kriteria agar lebih mudah dalam perhitungan selanjutnya. Hasil akhir yang didapatkan adalah proses penjumlahan dari setiap kriteria dengan memiliki hasil tertinggi $\mathbf{1 , 5 5 9 5 4 5 9 9 9 .}$

Kata Kunci - Gaji Karyawan, AHP, Pendukung Keputusan.

\section{PENDAHULUAN}

Dalam perusahan komputer memang sangat dibutuhkan untuk menunjang perkembangan perusahaan tersebut [1] Faktanya manusia tidak bisa dengan sempurna dalam mengolah berbagai data yang ada dalam perusahaan [2]. Pada salah satu usaha mebel di Kota Malang terdapat kegiatan yaitu pengolahan gaji karyawan. Dalam usaha mebel ini belum mempunyai sistem yang baik untuk penggajian karyawannya karena selama ini masih meggunakan cara manual yaitu menggunakan Micosoft Excel sehingga terdapat beberapa kendala yaitu keterlambatan perhitungan dan pencairan gaji [3].

Pada penelitian sebelumya sudah banyak dari peneliti mengembangkan metode AHP (Analytical Hierarchy Process) [4] salah satunya adalah dalam merancang sebuah sistem penunjang keputusan [5][6] dalam menentukan karyawan yang berhak untuk menerima bonus bersamaan dengan pemberian gaji pokok karyawan [7]. Berdasarkan permasalahan diatas peneliti menggunakan metode AHP [4] yang digunakan untuk membantu penentu gaji karyawan sesuai kriteria-kriteria yang sudah ditentukan dari tempat peneliti [7].

\section{METODE PENELITIAN}

\section{A. Tentang Usaha}

UD. Mebel DM adalah salah satu mebel yang ada di Kota Malang tepatnya berada di Jalan Ikan Kakap No. 40 RT 01 RW 06 Kelurahan Tunjungsekar Kecamatan Lowokwaru Kota Malang.

UD. Mebel DM juga menerima pesanan dalam pesanan yang di terima oleh UD. Mebel DM ini sangat beragam, misalnya seperti Almari, Kitchen Set, Spring Bed, Sofa, Bufet, Meja, dan Kursi. Dalam UD. Mebel DM ini tidak hanya membuat baru tapi juga bisa memperbaiki selagi masih bisa diperbaiki. Alat yang digunakan juga masih sama dengan usaha mebel lainnya. Bahan baku yang biasa digunakan yaitu Kayu atau Triplek dengan ketebalan yang sangat beragam. Untuk finishing biasanya dapat menggunakan plitur, sending dan HPL.

\section{B. Analisis Sistem yang berjalan}

Dengan mempelajari sistem yang lama pada UD. Mebel DM dalam menentukan gaji karyawan hanya dengan melihat dari berat pekerjaan seorang karyawam. Namun dalam pandangan dari penyusun KPP ini sangat kurang efisien. Jika dilihat dari beban pekerjaannya saja, dikarenakan jika pekerjaan pada salah satu karyawan selesai seorang karyawan ini tidak dapat mengerjakan atau membantu pekerjaan yang lebih ringan karena hanya diberi satu tanggung jawab pekerjaan saja.

Hal ini menyebabkan kurangnya loyalitas dan tanggung jawab atas sesama karyawan dalam UD. Mebel DM. Dengan demikian, penyusun KPP memberikan sebuah solusi untuk menentukan gaji karyawan yang memenuhi kriteria-kriteria yang sudah ditentukan dan disepakti oleh pemilik UD. Mebel DM dengan dibantu oleh sebuah sistem yang dibahas dalam penyusunan KPP ini.

\section{Perancangan Aplikasi}

Aplikasi penggajian ini dibuat untuk dapat memudahkan pemilik UD. Mebel DM dalam perhitungan gaji karyawannya sesuai dengan kriteria yang telah ditentukan. 


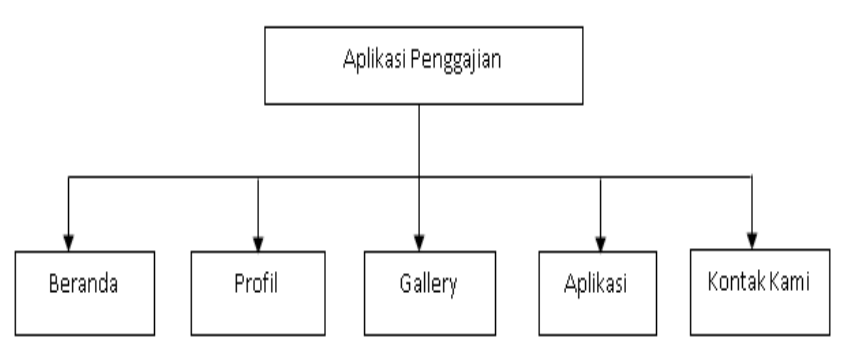

Gambar 3.1 Bagan Perancangan Aplikasi.

Penjelasan:

\section{Aplikasi Penggajian}

Menjelaskan suatu sistem yang dimana untuk menentukan nilai gaji karyawan pada aplikasi. Dan berisi beberapa menu selain aplikasi perhitungan penggajian karyawan.

\section{Beranda}

Merupakan menu awal dari halaman website aplikasi penggajian yang berisi tentang update tebaru dari informasi UD. Mebel DM.

\section{Profil}

Menu yang berisi profil UD. Mebel DM yang meliputi awal pendirian perusahaan.

\section{Gallery}

Menu yang berisi foto-foto dari hasil produksi yang dimiliki UD. Mebel DM.

\section{Aplikasi}

Menu yang berisi form untuk menghitung gaji karyawan UD. Mebel DM.

\section{Kontak Kami}

Menu yang berisi segala informasi untuk menghubungi UD. Mebel DM.

\section{Hasil dan Pembahasan}

Pemodelan dan perancangan sistem dalam penyusunan KPP ini menggunakan UML (Unified Modeling Language). Tahap-tahap pemodelan dalam analis is tersebut antara lain :

\section{1) Use Case Diagram}

Penjelasan :

1. Karyawan mengajukan pekerjaan kepada pemilik.

2. Pemilik menentukan penempatan pekerjaan.

3. Pemilik memberikan datakaryawan kepada admin.

4. Admin menentukan gaji karyawan.

5. Pemilik menyetujui gaji yang telah ditentukan.

6. Admin membuatkan slip gaji.

7. Karyawan menerima slip gaji.

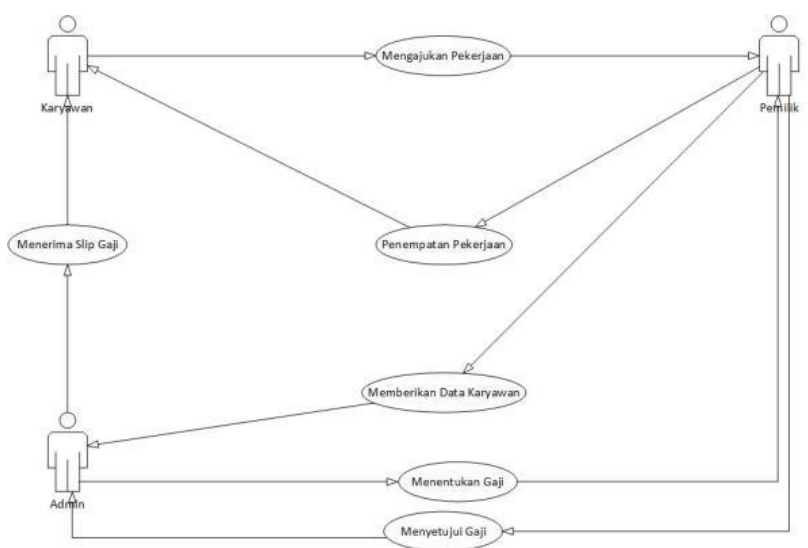

Gambar 3.2 Use Case Penentu Gaji.

2) Activity Diagram

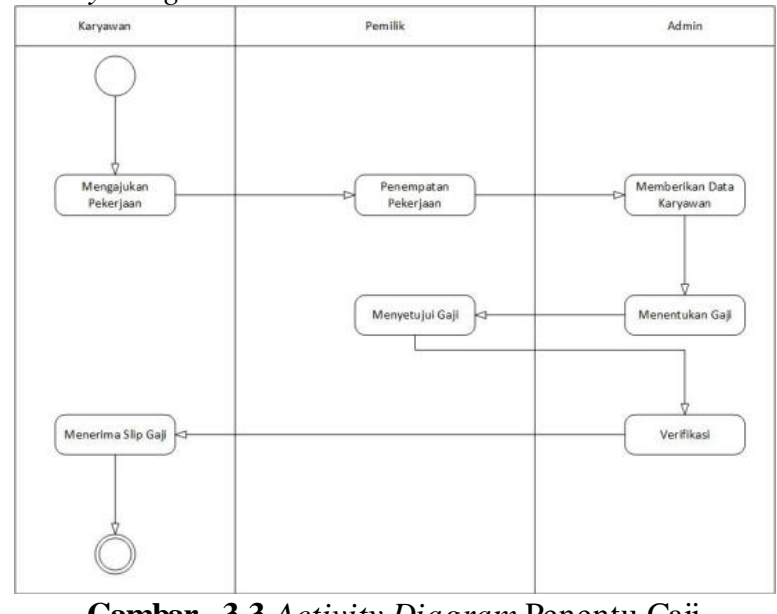

Gambar 3.3 Activity Diagram Penentu Gaji.

Penjelasan :

1. Karyawan mengajukan pekerjaan kepada pemilik.

2. Pemilik menentukan penempatan pekerjaan.

3. Pemilik memberikan data karyawan kepada admin.

4. Admin menentukan gaji karyawan.

5. Pemilik menyetujui gaji yang telah ditentukan.

6. Admin memverifikasi.

7. Karyawan menerima slip gaji.

\section{3) Sequence Diagram}

Penjelas an :

1. Karyawan mengajukan pekerjaan kepada pemilik.

2. Pemilik menentukan penempatan pekerjaan.

3. Karyawan menerima penempatan kerja.

4. Pemilik memberikan data karyawan kepada admin.

5. Admin menerima data karyawan.

6. Admin menentukan gaji karyawan.

7. Pemilik menyetujui gaji yang telah ditentukan.

8. Admin memverifikasi.

9. Admin membuat slip gaji.

10. Karyawan menerima slip gaji. 


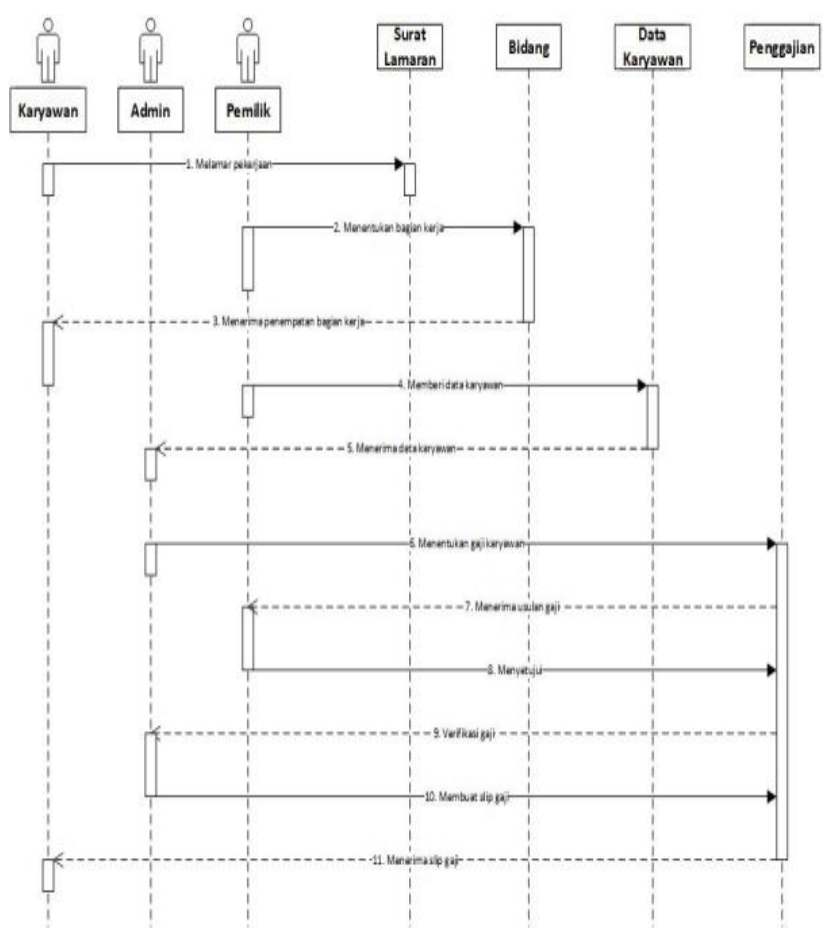

Gambar 3.4 Sequence Diagarm Penentu Gaji.

\section{E. Perancangan Antar Muka Pengguna}

\section{1) Tampilan Halaman Utama}

Halaman utama ialah tampilan awal yang dilihat oleh admin, disini admin bisa melihat apa saja dari menu menu yang disajikan.

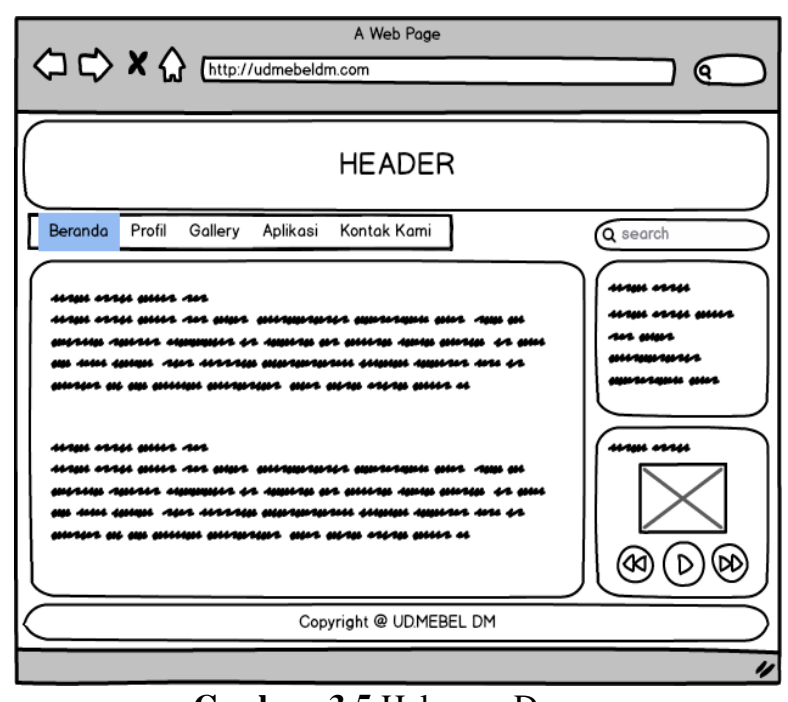

Gambar 3.5 Halaman Depan

\section{2) Halaman Profil UD. Mebel DM}

Menu yang berisi profil usaha UD. Mebel DM yang meliputi sejarah awal mula pendirian perusahaan hingga saat ini.

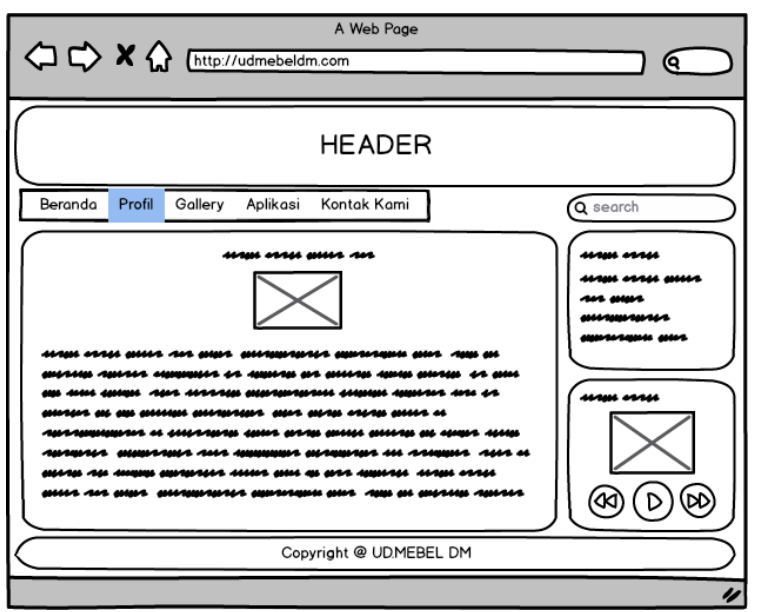

Gambar 3.6 Halaman Profil UD. Mebel DM.

3) Halaman Menu Gallery

Halaman Gallery berisi tentang dokumentasi foto hasil akhir dari sebuah produksi yang ada di UD. Mebel DM.

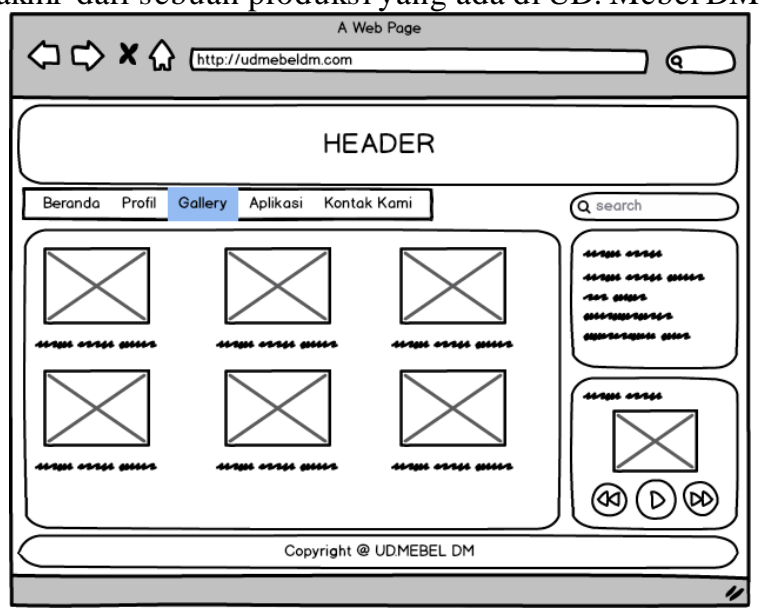

Gambar 3.7 Halaman Gallery UD. Mebel DM

4) Halaman Perhitungan Gaji

Menu yang berisi form untuk admin dalam menghitung gaji karyawan UD. Mebel DM.

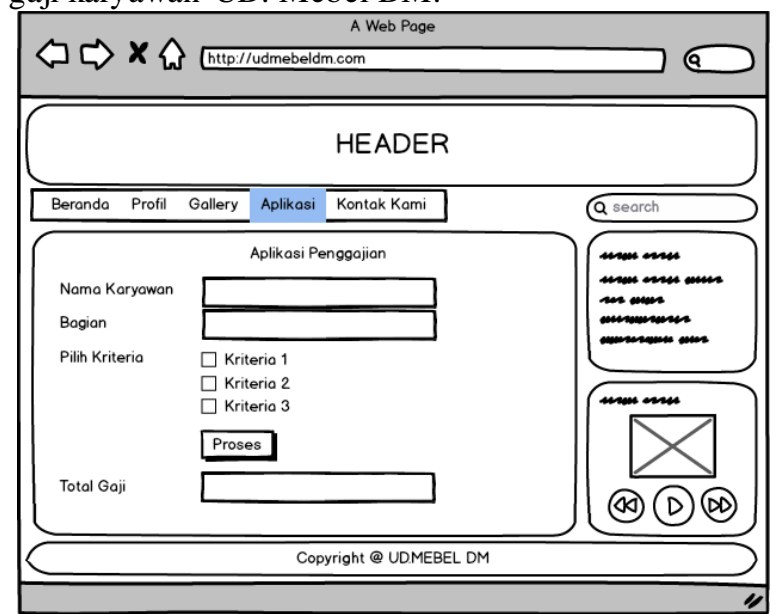

Gambar 3.8 Halaman Perhitungan Gaji. 


\section{F. Penerapan Perhitungan Metode AHP}

1) Menentukan Kriteria

Disini telah ditetukan kriterianya yaitu :

1. Kedisiplinan

2. Tanggung Jawab

3. Komitmen

4. Jujur

5. Etika

2) Menentukan Bobot Kriteria

Setelah ditentukan sebuah kriteria maka tahapan selanjutnya di tentukan sebuah bobot perbandingan antar kriteria, dengan rincian sebagai berikut :

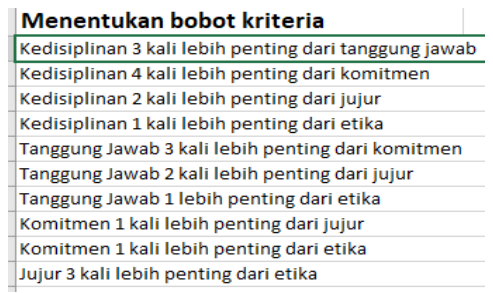

Menentukan bobot kriteria Kedisiplinan 3 kali lebih penting dari tanggung jawab Kedisiplinan 2 kali lebih penting dari komitmen jujur Kedisiplinan 2 kall lebih penting dari jujur Tanggung Jawab 3 kali lebih penting dari komitmen Tanggung Jawab 2 kali lebih penting dari jujur Tanggung Jawab 1 lebih penting dari etika Komitmen 1 kali lebih penting dari jujur Komitmen 1 kali lebih penting dari etik Jujur 3 kali lebih penting dari etika

Gambar 3.9 Menentukan Bobot Kriteria.

\section{HASIL DAN PEMBAHASAN}

\section{3) Perhitungan Setiap Kriteria}

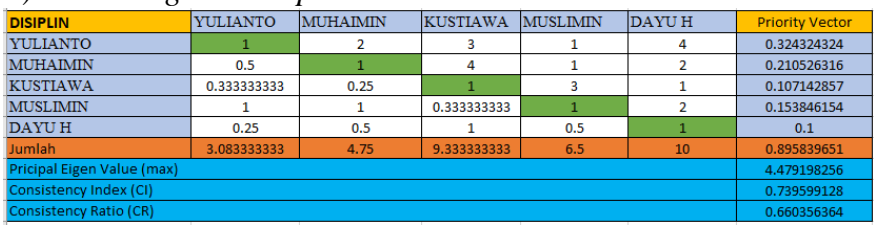

Gambar 3.10 Perhitungan Kriteria Disiplin.

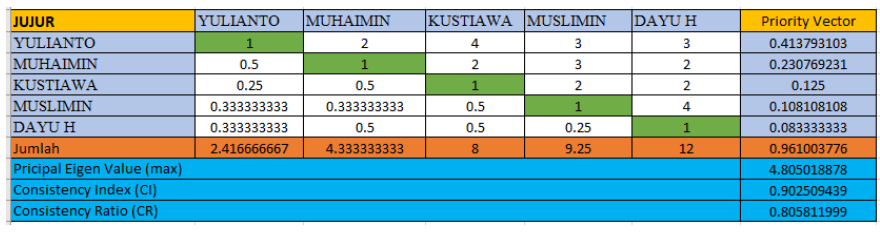

Gambar 3.11 Perhitungan Kriteria Jujur

Priority vector merupakan hasil penjumlahan dari semua cell sebelah kirinya pada baris yang sama. Setelah itu terlebih dahulu dibagi dengan cell jumlah yang ada di bawahnya,kemudian penjumlahan tersebut dibagi dengan angka 5 karena kriteria yang digunakan adalah 5.

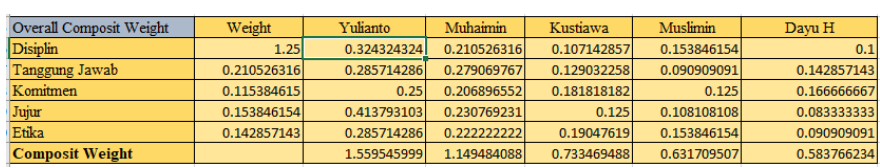

Gambar 3.12 Hasil Akhir Perhitungan Metode AHP.

Pada weight berisi jumlah Priority Vector pada penentuan nilai awal setiap kriteria. Untuk kolom nama karyawan dipasangkan dengan kriteria yang telah di tentukan. Nilainya diambil dari tabel sebelumnya dan untuk hasil akhirnya yaitu Composit Weight hanya menjumlahkan dari nilai-nilai yang ada diatasnya. Misalkan pada tabel diatas menunjukkan nilai Yulianto adalah 1,559545999 didapat dari penjumlahan $(0,324324324+0,285714286+0,25+0,413793103+$ $0,285714286)$.

\section{KESIMPULAN DAN SARAN}

Berdasarkan dari pengujian dan perhitungan menggunakan metode AHP maka dapat disimpulkan sebagai berikut: pemberian bobot pada setiap kriteria berpengaruh dalam hasil yang diperoleh dalam perhitungan metode AHP untuk menentukan gaji karyawan. Dengan menggunakan table index ratio akan mempermudah perhitungan metode AHP karena untuk menentukan sebuah nilai Consistency Ratio (CR). Setiap karyawan dinilai berdasarkan dari setiap kriteria yang ada dan dihasilkan sebuah nilai priority vector untuk penjumlah sebagai penentu nilai gaji terbaik. Penerapan sistem pendukung keputusan dalam menentukan gaji karyawan perlu diteleiti kembali dengan metode fuzzy. Supaya hasil yang diharapkan lebih baik lagi.

\section{DAFTAR PUSTAKA}

[1] P. N. Bali, N. Kadek, D. Hariyanti, and P. N. Bali, "PENGEMBANGAN SISTEM INFORMASI AKUNTANSI BERBASIS WEB PADA Jurusan Akuntansi, Politeknik Negeri Bali , Kampus Bukit Jimbaran , Jurusan Akuntansi , Politeknik Negeri Bali , Kampus Bukit Jimbaran, Jurusan Administrasi Niaga , Politeknik Negeri Bali , Kampus Bukit Jimbaran ," no. March 2017, 2015.

[2] B. Kuryanto and M. Syafruddin, "Pengaruh modal intelektual terhadap kinerja perusahaan," pp. 1-30.

[3] R. Bangun, S. Informasi, P. Dan, R. Jasa, M. Pada, and S. B. Surabaya, "Jurnal Sistem Informasi," vol. 3, no. 1, 2014.

[4] E. Nurmianto and A. H. Nasution, "PERUMUSAN STRATEGI KEMITRAAN MENGGUNAKAN METODE AHP DAN SWOT ( Studi Kasus pada Kemitraan PT . INKA dengan Industri Kecil Menengah di Wilayah Karesidenan Madiun )," pp. 47-60.

[5] A. Y. Rahman, M. Sa'adah, F. W. Setiawan, and E. Supriyanto, "Vice Presidential Election Prediction Period 2019- 2024 using Simple Additive Weighting," pp. 56-60, 2018.

[6] A. Y. Rahman, M. Sa'adah, F. W. Setiawan, A. L. Hananto, and E. Supriyanto, "Access Level File using Simple Additive Weighting," pp. 62-66, 2018.

[7] M. Muslihudin and S. Hartati, "GURU HONORER DI KABUPATEN PESAWARAN MENGGUNAKAN," vol. 9, pp. 83-88, 2016. 